With the constant risk of variation in response among species reliance on animal data may confuse clinical findings and thereby prove a wasteful detour. For instance, smoking and excessive alcohol consumption are major causes of morbidity and mortality in Western society, but attempts to reproduce many of their harmful effects in laboratory animals have met with little success. It has proved virtually impossible to induce lung cancer in animals by forcing them to inhale smoke, ${ }^{2}$ and the cause of alcohol induced liver cirrhosis has been doubted owing to failure to produce similar effects with alcohol in all common laboratory animals. 'Only the baboon reacts in a similar way to humans ${ }^{+}$and even this finding has now been disputed.

More could be achieved by reallocating resources to methods directly relevant to people, such as epidemiological, clinical, and necroscopic studies; work with healthy volunteers; and in vitro experiments with human cells and tissues. Indeed, progress by the study of humans is by no means unusual - it is more nearly the rule. ${ }^{5}$ Unfortunately, human based research requires more skill and patience to avoid unnecessary risks whereas animals are still regarded as disposable.

Even research that has come to rely on animals would not be halted by stopping the experiments as scientists would quickly devise new techniques to achieve their objectives. Historically, the lack of an animal model for chole $\mathrm{ra}^{6}$ and yellow fever ${ }^{7}$ did not stop research but forced investigators to concentrate on (ultimately more relevant) clinical and in vitro studies to identify the modes of transmission of these diseases so that eradication campaigns could be started.

The use of animals to test the potency of vaccines is traditional, but such an approach is of no value in assessing pneumonia vaccines because the causal organisms are generally not virulent in laboratory animals. Once again the lack of an animal model was the incentive to develop a successful and humane alternative based on chemical analysis and studies with human volunteers. ${ }^{*}$

The key to eliminating animal experiments lies in providing the necessary incentives. I hope that researchers do not react defensively but recognise the value to humans and animals of a more relevant approach to medical research and health care.

R SHARPE

International Association Against Painful Experiments on Animals, St Albans AL3 4RD

I Singer P. Experiments on animals. Br Med F 1989;299:1238-9. (18 November

2 Cross FT, Dagle GE, Gies RA. Reply to Dr Archer's comment on a histological study of the influence of cigarette smoking in a histological study of the influence of cigarette smoking in
suppressing Rn daughter carcinogenesis in dogs. Health Phys suppressing

3 Ainley CC, Senapati A, Brown IMH, et al. Is alcohol hepatotoxic in the baboon? $f$ Hepatol 1988:7:85-92.

4 Rubin E, Leiber CS Fatty liver, alcoholic hepatitis: a new primate model. N Engl f Med 1974;290:128-35.

5 Beeson PB. The growth of knowledge about a disease: hepatitis. Am F Med 1979;67:366-70

6 Koch R. An address on cholera and its bacillus. $\mathrm{Br}$ Med $\mathcal{F}$ 1884;ii:403-7, 453-9.

7 Altman LK. Who goes first? The story of self experimentation. New York: Random House, 1987

8 Robbins JB. The control of polyvalent pneumococcal polysaccharide vaccines. F Infect 1979;1(suppl 2):61-72.

SIR,-Professor Peter Singer in his editorial repeats his frequently made case against animal experiments, which is based on his extraordinary concept of "speciesism," a peculiar philosophy which has in the past been extensively used by the leaders of the extreme arm of the animal rights movement. It seems quite extraordinary that the $B M \mathcal{F}$, a journal devoted, I presume, to the alleviation of human suffering through the prevention and cure of disease, is prepared to lend its support to a view that equates animal with human lives. How many mice or fruit flies or nematodes are you prepared to equate to a human life?

As a result of Peter Singer's editorial journalists writing for the "popular" medical media and the lay press have clearly assumed that his diatribe represents the views of the $B M \mathcal{F}$ and, indeed, of the BMA itself. You have also handed an opportunity to those who produce the scurrilous and wildly inaccurate leaflets with which the children in our schools are bombarded, because these people will surely claim that their views now have the support of the medical establishment.

I never thought I should have to say in the columns of your distinguished journal that today's doctors are only able to help patients thanks to yesterday's animal experiments. I believe we stand on the brink of enormously exciting developments in cancer research, my own field, and shall be able to tackle the common cancers whose prevention and cure often elude us now. This will be possible only through a revolution in our understanding of the mechanisms underlying the origination and development of cancer; much of this understanding has depended on animal experiments. To learn more, and to develop that knowledge into practical benefits, we shall rely heavily on what those in the animal rights movement choose to call "alternative" research methods-developed largely by the scientists they revile-but ultimately work with animals will be essential to derive the practical benefits of these advances in cancer research, as in virtually all areas of medical research, where comparable progress is being made.

Peter Singer accuses us of being defensive. He is wrong. We are proud of the benefits to people brought about by medical research on animals, and we shall continue working in this way for the alleviation of human suffering just as long as it is necessary.

WALTER BODMER

Imperial Cancer Research Fund Laboratories,

London WC2A 3PX

1 Singer P. Experiments on animals. Br Med f 1989;299:1238-9. (18 November.)

** $\mathrm{BMJ}$ editorials are signed to indicate that the views expressed are those of the authors and are not necessarily shared by the journal or the BMA. Nevertheless, we do share Professor Singer's conviction that many research workers respond to any criticism with inappropriate hostility and defensiveness. Some experiments on animals in the past were indefensible; the essential experiments to which Sir Walter Bodmer refers will be tolerated by our society only if scientists are seen to recognise that their critics have a valid case and are seen really to be trying to limit the use of animals. $-\mathrm{ED}$, $B M \mathcal{F}$.

\section{Risks and benefits of antimalarial drugs}

SIR,-Professor Alasdair Breckenridge in his recent editorial wrote that chloroquine, by itself or with proguanil, or mefloquine should be used according to circumstances, and that few problems are encountered with chloroquine at the doses prescribed for malaria prophylaxis. ' Given the title of the editorial, however, the risk-albeit a small one- of convulsions associated with chloroquine used prophylacticly with or without other antimalarial drugs seems worthy of mention, particularly in view of the implications for people with epilepsy. We have recently come across seven such cases, six of which have been reported. ${ }^{23}$ We believe that doctors should be aware of the risk of antimalarial drugs provoking seizures, and before prescribing should inquire whether there is any history of epilepsy. Prospective travellers who have or have had epilepsy should be warned that there may be a risk of provoking seizures; then if they wish they can plan their itinerary to avoid the need to take antimalarial drugs. The action taken would depend on the destination, reasons for travel, and implications if a seizure occurred.

Professor Breckenridge also mentioned that special cases such as the pregnant traveller and the immunocompromised patient demand expert advice, but it would have been helpful if the article had included an outline of the advice that should be given to travellers with conditions that require special consideration or at least had indicated where it might be obtained.

D R FISH $M$ L E ESPIR

Institute of Neurology,

Queen Squar

London WCIN 3BG

1 Breckenridge A. Risks and benefits of prophylactic antimalarial drugs. Br Med f 1989;299:1057-8. (28 October.)

Fish DR, Espir MLE. Convulsions associated with prophylactic antimalarial drugs: implications for people with epilepsy. BrMed f 1988;297:526.

Fish DR, Espir MLE. Malaria prophylaxis and epilepsy. BrMed f 1988;297:1267.

\section{The future of Britain's mental hospitals}

SIR, - The concept of a health authority buying from a distant hospital a service for a particular group of patients is not a new one. County asylums offered just such facilities and the annual reports of Chester County Asylum from the turn of the century detail the arrangements. "Contracts" with different towns were negotiated, with clear financial costs per patient week. In 1901 Chester could boast a "profit" of over $£ 2000$ from treating patients from outside Chester county. The charges were: catchment area patients $41 \mathrm{p}$, Chester city $70 \mathrm{p}$, other counties $125 \mathrm{p}$, Cardiff (23 patients) and Melton (25 patients) $88 \mathrm{p}$. The actual cost to keep patients was $37 \mathrm{p}$, though a patient was given a grant of $35 p$ to live in the community.

Sadly for Chester, by 1904 patients from Melton had been removed, and a source of profit went with them. Cardiff was approached to fill the 25 vacancies at a $10 \%$ discount $(88 \mathrm{p}$ reduced to $80 \mathrm{p})$, though this was still twice the true cost to the asylum: $100 \%$ profit. Luckily Cardiff was slow with building its own asylum, so even in 1907 Chester could report that the contract with Cardiff had been extended for yet another year. The committee could "pay over $£ 2,200$ as excess charge received from Cardiff."

Visiting committees concerned themselves with the wellbeing of the patients but paid no attention to separation of people from their home areas, nor did they try to get good value for patients from monies paid by distant authorities. Today discharges from the long stay wards to the community are supposed to bring a dowry with them as part of care in the community arrangements.

M T MALCOLM

Department of Psychiatry

Clatterbridge Hospital,

Wirral

Merseyside I.63 $4 \mathrm{JY}$

SIR,-Professor R E Kendell's analysis of menta hospitals is obviously sensible in emphasising the need for a range of units and evaluative research. But his narrow understanding of community care as somehow "not hospital care" obscures the overriding issues of funding, staffing, and individualising the treatment of those with long term or recurrent mental illness. Asylum, in the sense of sanctuary, is certainly needed, but history tells us that the traditional asylum hospitals ("bins," "lunatic warehouses," "museums of madness") failed to deliver good quality care.

For example, the hospital scandals Professor Kendell mentions (rather blithely) as "embarrassing" were sordid and frightening events. The briefest reading of the inquiry reports would show 